\title{
MUCIN 1 in Prostate Cancer
}

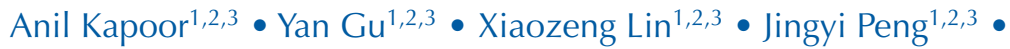 \\ Pierre Major ${ }^{4}$ - Damu Tang ${ }^{1,2,3}$ \\ ${ }^{1}$ Urological Cancer Center for Research and Innovation (UCCRI), St. Joseph's Hospital, \\ Hamilton, Ontario, Canada; ${ }^{2}$ The Research Institute of St Joe's Hamilton, Hamilton, \\ Ontario, Canada; ${ }^{3}$ Department of Surgery, McMaster University, Hamilton, Ontario, \\ Canada; ${ }^{4}$ Department of Oncology, McMaster University, Hamilton, Ontario, Canada
}

Author for correspondence: Damu Tang, Department of Surgery, McMaster University, Hamilton, Ontario, Canada. E-mail: damut@mcmaster.ca

Doi: https://doi.org/10.36255/exonpublications.prostatecancer.mucin1.2021

\begin{abstract}
Despite extensive research efforts in prostate cancer for the last several decades, the disease remains a leading cause of cancer death in men in the developed world. A typical feature of prostate cancer initiation and progression is the landscape of genetic alterations, which changes the expression patterns of numerous molecules in prostate epithelial cells, where the disease originates. These aberrantly expressed proteins are tumor-associated antigens. Their uniqueness in tumors offers an avenue not only in advancing our understanding of prostate cancer but also in the search for better diagnostic and therapeutic tools. Mucin 1 is one of the most well-characterized tumor-associated antigens. The protein is overexpressed and aberrantly glycosylated following prostate cancer development, and influences certain disease factors including disease initiation, metastasis, and resistance to therapy. Mucin 1 possesses value as a biomarker in predicting prostate cancer prognosis and has been studied as a therapeutic target. This chapter provides an overview of the impact of Mucin 1 on prostate cancer and its clinical values.
\end{abstract}

Keywords: biomarkers; mucin 1; prostate cancer; prostate cancer vaccine; therapy resistance

In: Prostate Cancer. Bott SRJ, Ng KL (Editors). Exon Publications, Brisbane, Australia. ISBN: 978-0-6450017-5-4; Doi: https://doi.org/10.36255/exonpublications.prostatecancer.2021

Copyright: The Authors.

License: This open access article is licenced under Creative Commons Attribution-NonCommercial 4.0 International (CC BY-NC 4.0) https://creativecommons.org/licenses/by-nc/4.0/ 


\section{INTRODUCTION}

Prostate cancer remains the most prevalent malignancy and the second leading cause of cancer-related death in men in the developed world (1). The disease originates from the prostate epithelial cells as prostatic intra-epithelial neoplasia and progresses to invasive carcinoma and metastatic prostate cancer $(2,3)$. Metastases occur frequently in the bone (4). Primary prostate cancers are commonly managed by active surveillance, and curative treatments including radical prostatectomy and radiation. Approximately 30\% of patients following radical prostatectomy will develop recurrent tumors or biochemical recurrence with rise in serum prostate-specific antigen (PSA) (5). Recurrent tumors are typically resistant to therapy, and relapsed prostate cancers or prostate cancers with resurged PSA are associated with higher risk of metastasis (6). Metastatic prostate cancers are treated with androgen deprivation therapy (ADT), which commonly leads to resistance in the form of castration-resistant prostate cancer (CRPC) $(7,8)$. There are multiple therapeutic options available for CRPCs, including taxane-based chemotherapy and those targeting androgen receptor signaling such as abiraterone or enzalutamide (8-10), and immunotherapy $(11,12)$. Despite this variety of treatment options, CRPC remains lethal $(8,13)$.

Cancer initiation, progression, and development of therapy resistance are regulated by complex processes, owing to the genetic and epigenetic changes that occur during the course of oncogenesis. These alterations result in a large number of unique tumor-associated antigens (TAAs) $(14,15)$. PSA as a classic prostate cancer TAA has been shown to generate PSA-specific T cells $(16,17)$. The nature of cancer-specific alterations (overexpression and modification) makes TAAs attractive targets for diagnostic and therapeutic purposes. Mucin 1 (MUC1) is one of the most well-characterized TAAs. MUCl promotes tumorigenesis by activating PI3K-AKT, MEK-ERK, and other molecular pathways (18). Overexpression, hypoglycosylation, and aberrant glycosylation of $\mathrm{MUCl}$ occur during prostate cancer initiation and progression. These changes are also associated with relapse and CRPC development. Thus, changes in MUCl can be used as a prognostic biomarker. As a TAA, MUCl has been explored as a target candidate for prostate cancer vaccine. This chapter provides an overview of the role of $\mathrm{MUCl}$ in prostate cancer. The biology of MUC1, its alterations during prostate cancer development and progression, and its potential as a therapeutic target along with its limitations and future research are discussed.

\section{THE BIOLOGY OF MUC1}

The MUC1 gene at 1q22 encodes mucin 1, a protein belonging to the 21-member mucin family in humans. Mucins are large proteins with extensive O-glycosylation and constitute the mucus barrier on epithelium to protect epithelial cells from external environment (19). MUCl was first detected in human milk fat globule and a set of breast cancer cell lines using anti-human milk fat globule serum (antiHMFG) (20); its membrane expression was subsequently observed at the apical surface of many glandular epithelial cells including those of the mammary gland, salivary gland, pancreas, prostate, uterus, as well as gastrointestinal and 
respiratory tracts $(21,22)$. MUCl plays a critical role in forming the protective mucus barrier on epithelial surfaces, evident by the significant reduction of mucus obstruction in cystic fibrosis mice with MUCl deficiency (23).

Cell surface MUCl is a heterodimer consisting of a large N-terminal extracellular subunit (MUC1-N or $\alpha$-subunit) and a small C-terminal subunit (MUC1-C or $\beta$-subunit) containing a small extracellular domain, a transmembrane motif, and a $\mathrm{C}$-terminal intracellular region; dimers are formed via non-covalent association in extracellular regions adjacent to cell membrane (Figure 1) (24). The two subunits are produced from a single polypeptide chain by autocleavage following the GSVVV sequence, which is located within the SEA (Sea urchin sperm protein enterokinase and agrin) domain, during translation (25). The N-terminal fragment contains variable number of tandem repeats (VNTR, $n=40-80$ ) of 20 amino acid residues $(26,27)$; MUC-N is enriched with proline, threonine, and serine (PTS) motifs and is extensively O-glycosylated such that the peptide core is mostly covered (Figure 1) (28). The heavy glycosylation contributes to MUCl's physiological functions in normal cells (28).

In cancer cells, MUCl is not only significantly upregulated but also undergoes aberrant glycosylation and hypoglycosylation in most cancers (29). Hypoglycosylation leads to exposure of VNTR peptides, which along with aberrant glycosylation change the biochemical properties and cell distributions of MUCl (28). These abnormalities underline MUCl's properties as a biomarker and therapeutic target as well as its functionality in promoting cancer progression.

\section{UPREGULATION OF MUC1 IN PROSTATE CANCER}

In a study of 2760 prostate cancer cases and 1722 controls, MUC1 gene variations in terms of single nucleotide polymorphisms and haplotype were not associated

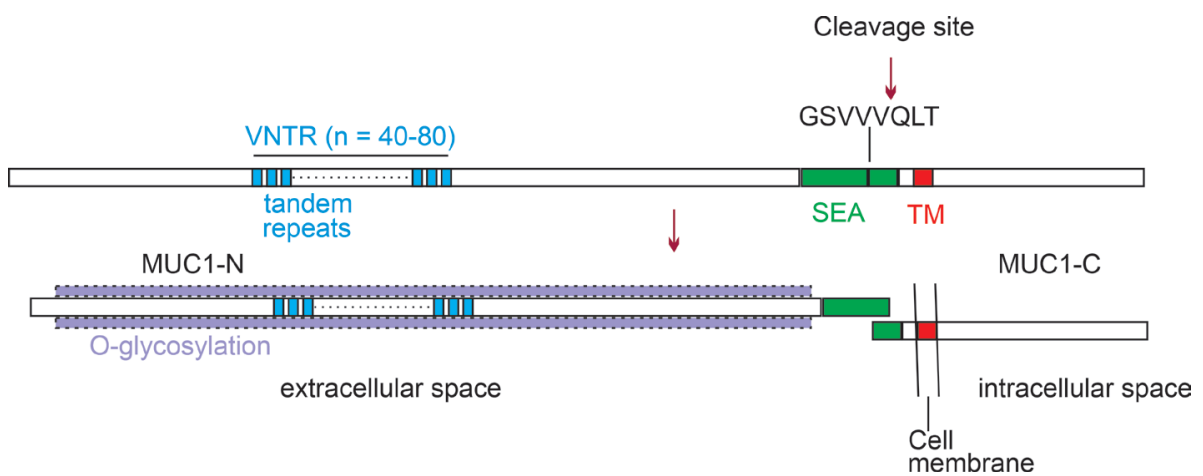

Figure 1. MUC1 heterodimer structure. MUC1 is cleaved at the indicated site, i.e., after GSVVV, during translation to generate the MUC1-N and MUC1-C subunits. Both subunits form a heterodimer in the extracellular space adjacent to cell membrane. MUC1-N is extensively O-glycosylated as indicated. SEA (Sea urchin sperm protein enterokinase and agrin) and TM (transmembrane) domains are indicated. VNTR, variable number of tandem repeats. 
with prostate cancer risk and disease progression (30). In an investigation of primary prostate cancers $(n=333)$, metastatic prostate cancers $(n=150)$, and CRPCs $(n=77)$, an increase in MUC1 gene copy number was observed in 35\% of CRPCs compared to $6 \%$ and $1.8 \%$ in mPCs and primary PCs, respectively (31), indicating that MUC1 gene amplification contributes to MUCl upregulation in CRPCs.

In a NanoString-based gene expression analysis using 7 pairs of primary prostate cancers and matched non-tumor tissues, MUCl mRNA was increased in four prostate cancer samples compared to their matched non-tumor controls; 5 of the PC tissues showed elevations of ERG expression (demonstrative of TMPRSS2ERG fusion) and downregulation of PTEN, both common molecular alterations in prostate cancer oncogenesis (31). However, in an analysis of multiple cohorts consisting of 221 prostate cancers and 92 normal prostate tissues, MUC1 mRNA expression was shown to be reduced (31). Nonetheless, high level of MUC1 mRNA expression likely correlates with TMPRSS2-ERG fusion based on data from the Sueltman dataset (Figure 2A) (32). TMPRSS2-ERG fusion occurs commonly in prostate cancer and plays important roles in its initiation and progression $(33,34)$. Additionally, microarray-based gene expression profiling of 62 primary prostate cancers and 41 normal prostate tissues revealed increases in MUCl mRNA expression in high-grade and advanced prostate cancers (35). Collectively, while current evidence does not conclusively support upregulation of MUC1 gene expression during prostate cancer initiation, elevations in MUCl mRNA largely correlate with prostate cancer progression.

The above concept is supported by increases in MUCl mRNA expression in metastatic prostate cancers. In two independent cohorts containing 54 metastatic prostate cancers compared to 82 normal prostate tissues, higher levels of MUCl mRNA were observed in metastatic cases (31). Elevation of MUC1 mRNA in metastatic prostate cancer could also be demonstrated using the well-established Sawyers dataset (36) organized by the R2: Genomics Analysis and Visualization Platform (http://r2.amc.nl http://r2platform.com) (Figure 2B).
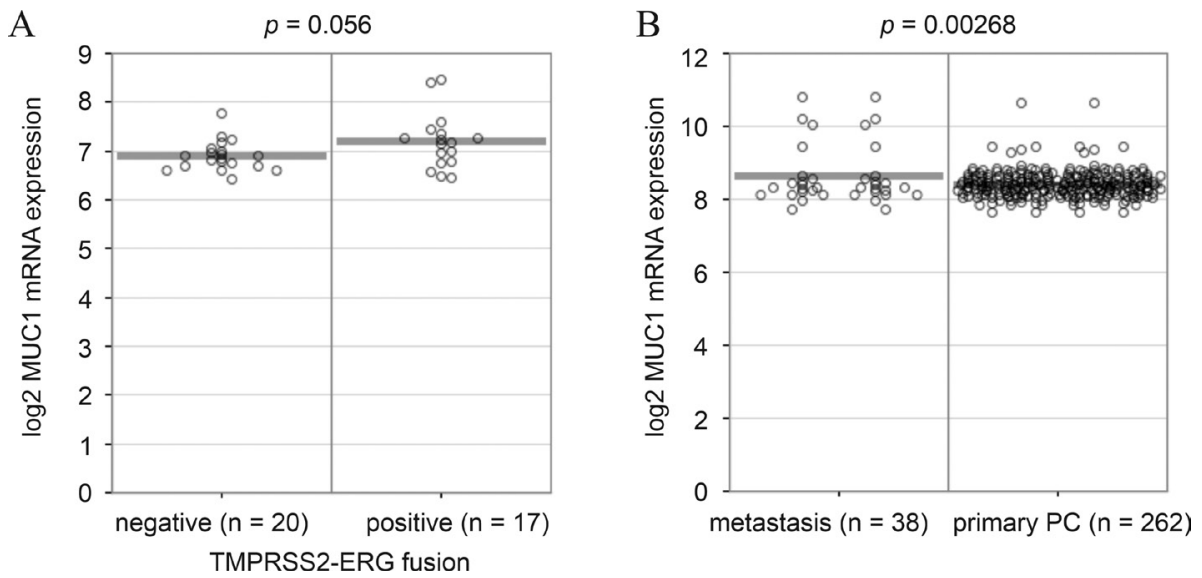

Figure 2. MUC1 expression is associated with adverse features of PC. A. Analyses were performed using the Sueltman dataset (45) in R2: Genomics Analysis and Visualization Platform. B. Analyses were performed using the Sawyers dataset (49) in R2: Genomics. Statistical analyses were performed by the R2 Platform using one-way ANOVA. 
MUCl expression was observed in prostate epithelial cells and prostate adenocarcinoma more than two decades ago using two anti-MUCl monoclonal antibodies (mAb) DF3 and 139H2 (22). Immunohistochemistry staining with B27.29, which recognizes the peptide core (37), showed enhanced MUCl protein expression in prostate cancer compared to normal prostate glandular epithelial cells (38). Hypoglycosylation of prostate cancer-associated MUCl was demonstrated by its preferential recognition of prostate cancer cells compared to nontumor prostate epithelial cells using antibodies BrE-3, BC2, and EMA; these mAbs bind to the peptide core. The upregulation of hypoglycosylated MUCl positively correlates with Gleason scores (39) and cancer progression (40, 41) (Table 1).

Reduction in O-glycosylation in tumor-associated MUCl is also caused by premature termination of chain elongation, which is in part attributed to the addition of sialic acid, leading to MUC1 being highly sialylated in tumors (28). In line with this concept, mAb MY.1E12 which reacts with sialylated MUC1 $(42,43)$, detects MUCl upregulation and is correlated with prostate cancer grade (44). Elevation of 2 O-linked glycan syalyl Lewis X (sLe ${ }^{\mathrm{x}}$ ) MUCl occurs in prostate cancer (Table 1), which might be in part attributable to the upregulation of GCNT1 glycosyltransferase in prostate cancer (45).

While evidence collectively supports overexpression of aberrantly glycosylated MUCl in prostate cancer, it remains unclear whether the "upregulation" detected by antibodies recognizing the altered forms truly reflects MUC1 upregulation, as aberrantly modified MUCl is present in prostate epithelial cells. This limitation is reflected in immunohistochemistry analysis using $\mathrm{mAb} \mathrm{MBC}-2$, which revealed MUCl positivity in $28 \%$ of primary prostate cancers (9/32), and $22 \%$ of nontumor prostate tissues (15/68) (46). Similarly, MUCl protein was detected in 17\%

\section{TABLE 1 MUC1 upregulation in prostate cancer ${ }^{\mathrm{a}}$}

\begin{tabular}{|c|c|c|c|c|}
\hline Population $(n)^{b}$ & MAb & $\begin{array}{c}\% \text { of } \\
\text { positive }\end{array}$ & Association $^{\mathrm{C}}$ & Reference \\
\hline 10 & $\begin{array}{c}\mathrm{DF} 3 \\
139 \mathrm{H} 2\end{array}$ & $\begin{array}{l}100 \% \\
100 \%\end{array}$ & NA & $(22)$ \\
\hline 5 & B27.29 & NA & NA & (38) \\
\hline 24 & BrE-3, BC2, EMA & NA & $\begin{array}{l}\text { Upregulation in PC and higher } \\
\text { Gleason grade PC }\end{array}$ & (39) \\
\hline $\begin{array}{l}120 \text { primary PC } \\
10 \mathrm{LN} \mathrm{mPC}\end{array}$ & C595 & $\begin{array}{l}58 \% \\
90 \%\end{array}$ & $\begin{array}{l}\text { Upregulation in PC and higher } \\
\text { Gleason grade PC }\end{array}$ & $(40)$ \\
\hline $9 \mathrm{mPC}$ & HMFG-2 & $55.5 \%{ }^{\mathrm{d}}$ & Upregulation in $\mathrm{mPC}$ & $(41)$ \\
\hline 57 & MY.1E12 & NA & $\begin{array}{l}\text { Upregulation in PC and higher } \\
\text { Gleason grade PC }\end{array}$ & (44) \\
\hline 10 & $\mathrm{CHO} 131$ & NA & NA & $(45)$ \\
\hline
\end{tabular}

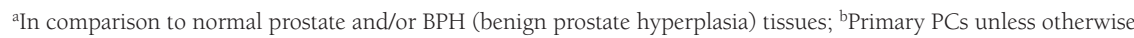
indicated; ' Association with PC severity; ${ }^{\mathrm{d}}$ Positivity was defined by MUCl-positive cells $>50 \%$ of total tumor cells. LN $\mathrm{mPC}$, lymph node metastasis; $\mathrm{mPC}$, distant metastasis; NA, not available. 
(30/175) of prostate cancer and 41\% (42/103) of non-tumor tissues using the VNTR-specific, but glycosylation-insensitive, anti-MUCl antibody 214D4 (47). It is thus important to further examine $\mathrm{MUCl}$ upregulation using gene expression and genetic approaches.

While the mechanisms responsible for MUCl upregulation in prostate cancer at either the protein or mRNA level are still largely unknown, prostate cancer stem cells (PCSC) may play a role in this process. Sphere cells derived from DU145 cells possess PCSC properties (48) and display significant upregulation of MUCl at both the protein and mRNA level compared to their non-stem cancer counterparts (31). Higher levels of MUCl were also detected in xenografts generated from DU145 PCSC-like sphere cells compared to tumors produced by non-stem cancer DU145 cells (31). Evidence indicates that mechanisms regulating PCSCs might be important in MUCl upregulation in prostate cancer. This notion is in accordance with the expression of $\mathrm{MUCl}^{*}$, a MUC-1C fragment missing the N-terminal 13 residues from its 58 residues of the extracellular domain in human embryonic stem cells (hESCs) (49). PCSCs are a major driver of prostate cancer progression and development of therapy resistance, including CRPC (50).

\section{MUC1 AND PROSTATE CANCER PROGRESSION}

Resistance to ADT or the generation of CRPC remains the inevitable, lethal progression of prostate cancer, to which PCSC is a major contributor (50). Of note, upregulation of MUCl has been demonstrated in human CRPCs, LNCaP cellderived CRPC xenografts, and CRPC produced in castrated prostate-specific $\mathrm{PTEN}^{-/-}$mice $(31,51)$. MUC1 promotes CRPC in part via enhancement of PCSC. MUC1-C induces the expression of the pluripotent genes OCT4, SOX2, LKF4, and MYC in prostate cancer cells, facilitates PCSCs, and promotes CRPC development (52). Intriguingly, MUCl* maintains the self-renewal of hESCs via binding to NM23-H1, a metastasis-associated protein (49). MUC1-C enhances prostate cancer plasticity partly through suppression of AR signaling (52). MUC1-C reduces AR signaling via association with ARs and activating miR-135 that downregulates ARs (53). ARs downregulate MUCl expression in LNCaP cells via binding to the MUC1 promoter, and also through induction of miR-125b that inhibits MUCl expression (54). The AR-derived suppression of MUCl expression might be a contributor for LNCaP cells being MUC1-negative (55). While these observations support mutual inhibition between ARs and MUCl expression in prostate cancer, their relationship is complex; ectopic expression of ARs in AR-negative PC3 cells upregulated MUCl following stimulation with $5 \alpha$-dihydrotestosterone (DHT) (56). Similar observations were also obtained in AR-negative DU145 cells with ectopic AR expression (57).

Induction of MUC1 by androgens in DU145-AR and PC3-AR cells decreased cell adhesion $(56,57)$. Upregulation of MUC1 in PC3 cells by arctiin also reduced cell adhesion (58), supporting the idea that MUC1 plays an important role in decreasing cell adhesion, which may facilitate metastasis. This possibility is reinforced by the production of sialyl Lewis a ( $\left.s L e^{a}\right)$ modification on MUCl upon its ectopic expression in low MUCl expression LNCaP and PC3 cells (59). 
MUCl with the sLe $e^{a}$ and sLe $e^{\mathrm{x}}$ antigen are selectin ligands (60-62); the interaction between cancer cells and selectin plays a critical role in the extravasation of cancer cells from blood vessel to tissues during metastasis (63). MUCl may enhance metastasis via multiple mechanisms. For example, MUCl-C can induce the epithelial-mesenchymal transition (EMT) (53), an essential process of metastasis. $\mathrm{MUCl}$ also enhances prostate cancer progression through other mechanisms. The inhibition of AMPKa activity by MUCl in vivo promotes CRPC development; conversely, AMPKa suppresses CRPC in part by inhibition of MUCl expression (64). While the detailed mechanisms are still unclear, MUCl expression in prostate cancer is associated with angiogenesis (65) and evasion of natural killer cell-derived immunity (66). Downregulation of $\mathrm{MUCl}$ expression by miR-326 inhibited cell proliferation in vitro and xenograft formation in vivo; the inhibitions were neutralized upon MUCl re-expression (67). Collectively, a large body of evidence reveals that $\mathrm{MUCl}$ plays a role in promoting prostate cancer progression through modulating multiple oncogenic processes, including angiogenesis, metastasis, and CRPC development. These properties might be attributed to MUCl-C's action in promoting growth factor receptor signaling, PI3K-AKT-mTOR, MEKERK, and cancer metabolism (18).

\section{MUC1-MEDIATED PREDICTION OF PROSTATE CANCER PROGNOSIS}

The upregulation of aberrant glycosylation along with its functional contributions to prostate cancer underlines MUCl's potential as a prognostic biomarker. MUCl expression can be used for risk stratification (44), predicting tumor volume, stage, metastasis $(68)$, recurrence-free survival $(35,69)$ and mortality risk $(70)$. MUCl-mediated prediction of prostate cancer recurrence and fatality can be improved with multiple gene panels consisting of MUCl+AZGPl (35) and $\mathrm{MUCl}+\mathrm{AZGP1}+\mathrm{p} 53$ (70), respectively. Furthermore, MUCl-associated genes or its network predicted prostate cancer relapse with high level of certainty $(51,71)$. Collectively, accumulative evidence supports an association of high MUCl expression with poor prognosis of PC (Table 2).

Nonetheless, the prognostic role of MUCl in prostate cancer might be much more complex. In a tissue microarray analysis of early-stage prostate cancer (Tla-b, Nx, M0; $\mathrm{n}=195$ ) under watchful waiting for 20 years, tumors with either high- or low-MUCl expression were associated with a higher risk of fatality compared to those with moderate $\mathrm{MUCl}$ expression comparable to normal prostate epithelium (72). MUCl's prognostic potential was independent of Gleason score and tumor stage (72). The observed higher risk of death for earlystage prostate cancers with reduced MUCl expression needs further investigation. Nonetheless, this study indicates a complex relationship between MUC1 expression and prostate cancer progression, a concept that is in line with the observations that overexpression of MUCl in LNCaP C4-2B4 cells was neither stimulative nor inhibitive of xenograft formation (73). Collectively, more work is needed to translate the knowledge generated in laboratory into clinical applications. 


\begin{tabular}{lcccc}
\hline TABLE 2 & \multicolumn{4}{l}{ MUC1-associated prognostic biomarker value } \\
\hline Population (n) & Progression & HR $(\mathbf{9 5} \% \mathbf{C l})^{\mathrm{a}}$ & p value & Reference \\
\hline 57 & PFS & $5.23(1.83-14.97$ & $0.002^{* *}$ & $(44)$ \\
225 & RFS & $2.35(1.30-4.24)$ & $0.0005^{* * *}$ & $(35)$ \\
$119^{\mathrm{b}}$ & DSS & $3.2(1.5-7.0)^{\mathrm{c}}$ & $0.0382^{*}$ & $(68)$ \\
1326 & RFS & $1.24(1.02-1.49)$ & $0.02^{*}$ & $(69)$ \\
$315^{\mathrm{d}}$ & OS & $2.51(1.14-5.54)$ & $0.02^{*}$ & $(70)$ \\
$485^{\mathrm{e}}$ & DFS & $2.38(1.55-3.58)$ & $3.45 \mathrm{E}-05^{* * *}$ & $(51)$
\end{tabular}

annivariate Cox analysis unless otherwise specified; 'PPatients with LN metastasis; ${ }^{c}$ Multivariate Cox analysis including Gleason scores; ${ }^{\mathrm{d}}$ Mortality cases $\mathrm{n}=83$; ${ }^{\mathrm{e}} \mathrm{A}$ nine-gene panel derived from MUCl-associated genes. DFS, disease free survival; DSS, disease-specific survival; OS, overall survival; PFS, progression free survival; RFS, recurrence free survival; ${ }^{*} \mathrm{p}<0.05,{ }^{* *} \mathrm{p}<0.01$, and $* * * \mathrm{p}<0.001$.

\section{MUC1 AS A THERAPEUTIC TARGET FOR PROSTATE CANCER}

As a TAA, MUC1 has been examined as a target for immunotherapy for prostate cancer. In an in vitro model, chimeric antigen receptor (CAR)-MUCl T cells were produced and shown to be effective in killing PC3 and DU145 cells; they also increased the cytotoxicity of AR-positive LNCaP cells together with flutamide, an anti-androgen (74). Tecemotide or L-BLP25 is a cancer vaccine targeting the tandem repeats of MUCl and has been under clinical trials for a variety of cancers, including a phase III trial for non-small cell lung carcinoma (NSCLC) $(75,76)$. A phase II clinical trial has been conducted on 16 patients who had biochemical recurrence following radical prostatectomy. Of these, six patients showed prolonged PSA doubling time (PSADT) (77). In a phase I/II clinical trial (NCT00852007) on 17 patients with non-metastatic CRPC, autologous dendritic cells were stimulated with a Tn-MUCl peptide in vitro, and upon reintroduction to patients, it significantly improved PSADT in 11 patients and induced Tn-MUCl specific $\mathrm{CD}^{+}$and $\mathrm{CD}^{+} \mathrm{T}$ cell response in five of the seven patients analyzed (78). In a randomized phase IIa clinical trial on 21 chemonaïve CRPC patients with dendritic cells loaded with NY-ESO-1, MAGE-C2, and MUCl peptides, specific T cell responses were detected and in patients with IFN- $\gamma^{+} \mathrm{T}$ cells, extension of median radiological progression-free survival was observed (79).

MUCl has also been targeted using a virus-based vaccine. TG4010 is a recombinant vaccinia virus Ankara expressing MUC1 and IL2. In a phase II clinical trial on 40 prostate cancer patients with PSA progression treated with TG4010, 13 patients had at least a 2-fold improvement in PSADT, and 10 patients had stabilized PSA for more than 8 months (80). Although the primary objective of a 50\% PSA reduction from base line was not achieved, inclusion of 
MUCl in the vaccine provided some therapeutic benefits. Collectively, the above observations support MUCl being a useful TAA for developing prostate cancer vaccine.

\section{CONCLUSION}

Since its discovery as a component of human milk fat globule in 1977 (20), MUC1 has been extensively studied in cancer, particularly in epithelium-originated malignancy; it is commonly overexpressed with aberrant glycosylation in numerous cancer types (19), including prostate cancer. Despite some inconsistencies (46), cumulative evidence clearly reveals $\mathrm{MUCl}$ upregulation in prostate cancer, and its possible role in initiation, progression, and metastasis of prostate cancer. While $\mathrm{MUCl}$ expression does show prognostic value, this prediction is not robust and should be strengthened by multigene panels for potential clinical application. In this regard, the multigene panels derived from MUCl's network $(51,71)$ should be explored for clinical applications. While MUCl as a TAA has clinical benefits as a vaccine, its therapeutic potential seems limited based on several clinical trials in which $\mathrm{MUCl}$ tandem repeat peptide core and aberrant glycosylation have been used. Approaches to inhibition of MUCl-C warrant more attention. Of note, GO-201, a synthetic peptide that inhibits MUCl-C oligomerization displays antiprostate cancer activity in preclinical studies (81). Additionally, upon linkage to ZZ-PE38, the Fc-binding ZZ domain of protein A fused to Pseudomonas exotoxin (82), a humanized mAb DMB5F3 potently killed $\mathrm{MUCl}^{+}$cancer cells (83). DMB5F3 recognizes the SEA domain shared between MUCl-N and MUC1-C (83). The therapeutic utility of GO-201 and DMB5F3-ZZ-PE38 in treating prostate cancer should be investigated either alone or together with the current MUCl vaccines. Further, the role of $\mathrm{MUCl}$ on $\mathrm{MUC1}^{-1}$ mice and $\mathrm{MUCl}$ transgenic animals should be investigated. Both mouse lines are available $(84,85)$. Transgenic expression of human MUCl in mice did not cause tumor formation (85). $\mathrm{MUC1}^{-1-}$ mice were normal (84) but showed delay in mammary tumor formation induced by polyoma middle T antigen (84). It will be interesting to see the impact of these mice on research into prostate cancer formation and progression induced by prostate-specific PTEN deficiency.

Acknowledgement: Damu Tang is supported by grants from Cancer Research Society, Canadian Cancer Society (grant \#: 319412) and CIHR and by funds from Urological Cancer Center for Research and Innovation (UCCRI), Hamilton. Yan $\mathrm{Gu}$ is supported by Studentship provided by Ontario Graduate Scholarships and Research Institute of St Joe's Hamilton.

Conflicts of interest: The authors declare no potential conflict of interest with respect to research, authorship and/or publication of this chapter.

Copyright and permission statement: The authors confirm that the materials included in this chapter do not violate copyright laws. Where relevant, appropriate permissions have been obtained from the original copyright holder(s), and all original sources have been appropriately acknowledged or referenced. 


\section{REFERENCES}

1. Siegel R, Ward E, Brawley O, Jemal A. Cancer statistics, 2011: the impact of eliminating socioeconomic and racial disparities on premature cancer deaths. CA: a cancer journal for clinicians. 2011;61(4):212-36. https://doi.org/10.3322/caac.20121

2. Ross JS. The androgen receptor in prostate cancer: therapy target in search of an integrated diagnostic test. Adv Anat Pathol. 2007;14(5):353-7. https://doi.org/10.1097/PAP.0b013e31814a52c4

3. Moon C, Park JC, Chae YK, Yun JH, Kim S. Current status of experimental therapeutics for prostate cancer. Cancer Lett. 2008;266(2):116-34. https://doi.org/10.1016/j.canlet.2008.02.065

4. Bagnall P. Diagnosis and treatment of prostate cancer. Nurs Times. 2014;110(9):12-5.

5. Zaorsky NG, Raj GV, Trabulsi EJ, Lin J, Den RB. The dilemma of a rising prostate-specific antigen level after local therapy: what are our options? Semin Oncol. 2013;40(3):322-36. https://doi. org/10.1053/j.seminoncol.2013.04.011

6. Shipley WU, Seiferheld W, Lukka HR, Major PP, Heney NM, Grignon DJ, et al. Radiation with or without Antiandrogen Therapy in Recurrent Prostate Cancer. N Engl J Med. 2017;376(5):417-28. https://doi.org/10.1056/NEJMoa1607529

7. Semenas J, Allegrucci C, Boorjian SA, Mongan NP, Persson JL. Overcoming drug resistance and treating advanced prostate cancer. Curr Drug Targets. 2012;13(10):1308-23. https://doi. org/10.2174/138945012802429615

8. Ojo D, Lin X, Wong N, Gu Y, Tang D. Prostate Cancer Stem-like Cells Contribute to the Development of Castration-Resistant Prostate Cancer. Cancers. 2015;7(4):2290-308. https://doi.org/10.3390/ cancers 7040890

9. de Bono JS, Logothetis CJ, Molina A, Fizazi K, North S, Chu L, et al. Abiraterone and increased survival in metastatic prostate cancer. N Engl J Med. 2011;364(21):1995-2005. https://doi.org/10.1056/ NEJMoal014618

10. Scher HI, Fizazi K, Saad F, Taplin ME, Sternberg CN, Miller K, et al. Increased survival with enzalutamide in prostate cancer after chemotherapy. N Engl J Med. 2012;367(13):1187-97. https://doi. org/10.1056/NEJMoal207506

11. Chaturvedi S, Garcia JA. Novel agents in the management of castration resistant prostate cancer. J Carcinog. 2014;13:5. https://doi.org/10.4103/1477-3163.128185

12. Drake CG. Prostate cancer as a model for tumour immunotherapy. Nat Rev Immunol. 2010;10(8): 580-93. https://doi.org/10.1038/nri2817

13. Mei W, Gu Y, Jiang Y, Major P, Tang D. Circulating cell-free DNA is a potential prognostic biomarker of metastatic castration-resistant prostate cancer for taxane therapy. AME Med J. 2018;3(68):1-5. https://doi.org/10.21037/amj.2018.06.01

14. Buonaguro L, Petrizzo A, Tornesello ML, Buonaguro FM. Translating tumor antigens into cancer vaccines. Clin Vaccine Immunol. 2011;18(1):23-34. https://doi.org/10.1128/CVI.00286-10

15. de Paula Peres L, da Luz FA, Dos Anjos Pultz B, Brigido PC, de Araujo RA, Goulart LR, et al. Peptide vaccines in breast cancer: The immunological basis for clinical response. Biotechnol Adv. 2015;33(8):1868-77. https://doi.org/10.1016/j.biotechadv.2015.10.013

16. Correale P, Walmsley K, Nieroda C, Zaremba S, Zhu M, Schlom J, et al. In vitro generation of human cytotoxic T lymphocytes specific for peptides derived from prostate-specific antigen. J Natl Cancer Inst. 1997;89(4):293-300. https://doi.org/10.1093/jnci/89.4.293

17. Corman JM, Sercarz EE, Nanda NK. Recognition of prostate-specific antigenic peptide determinants by human CD4 and CD8 T cells. Clin Exp Immunol. 1998;114(2):166-72. https://doi. org/10.1046/j.1365-2249.1998.00678.x

18. Kufe DW. MUC1-C oncoprotein as a target in breast cancer: activation of signaling pathways and therapeutic approaches. Oncogene. 2013;32(9):1073-81. https://doi.org/10.1038/onc.2012.158

19. Kufe DW. Mucins in cancer: function, prognosis and therapy. Nature reviews Cancer. 2009;9(12): 874-85. https://doi.org/10.1038/nrc2761

20. Ceriani RL, Thompson K, Peterson JA, Abraham S. Surface differentiation antigens of human mammary epithelial cells carried on the human milk fat globule. Proc Natl Acad Sci U S A. 1977;74(2): 582-6. https://doi.org/10.1073/pnas.74.2.582 
21. Gendler SJ. MUCl, the renaissance molecule. J Mammary Gland Biol Neoplasia. 2001;6(3):339-53. https://doi.org/10.1023/A:1011379725811

22. Ho SB, Niehans GA, Lyftogt C, Yan PS, Cherwitz DL, Gum ET, et al. Heterogeneity of mucin gene expression in normal and neoplastic tissues. Cancer Res. 1993;53(3):641-51.

23. Parmley RR, Gendler SJ. Cystic fibrosis mice lacking Mucl have reduced amounts of intestinal mucus. J Clin Invest. 1998;102(10):1798-806. https://doi.org/10.1172/JCI3820

24. Ligtenberg MJ, Kruijshaar L, Buijs F, van Meijer M, Litvinov SV, Hilkens J. Cell-associated episialin is a complex containing two proteins derived from a common precursor. J Biol Chem. 1992;267(9): 6171-7. https://doi.org/10.1016/S0021-9258(18)42677-4

25. Levitin F, Stern O, Weiss M, Gil-Henn C, Ziv R, Prokocimer Z, et al. The MUC1 SEA module is a selfcleaving domain. J Biol Chem. 2005;280(39):33374-86. https://doi.org/10.1074/jbc.M506047200

26. Hanisch FG, Muller S. MUCl: the polymorphic appearance of a human mucin. Glycobiology. 2000;10(5):439-49. https://doi.org/10.1093/glycob/10.5.439

27. Gendler SJ, Lancaster CA, Taylor-Papadimitriou J, Duhig T, Peat N, Burchell J, et al. Molecular cloning and expression of human tumor-associated polymorphic epithelial mucin. J Biol Chem. 1990;265(25):15286-93. https://doi.org/10.1016/S0021-9258(18)77254-2

28. Nath S, Mukherjee P. MUCl: a multifaceted oncoprotein with a key role in cancer progression. Trends Mol Med. 2014;20(6):332-42. https://doi.org/10.1016/j.molmed.2014.02.007

29. Lau SK, Weiss LM, Chu PG. Differential expression of MUC1, MUC2, and MUC5AC in carcinomas of various sites: an immunohistochemical study. Am J Clin Pathol. 2004;122(1):61-9. https://doi. org/10.1309/9R6673QEC06D86Y4

30. Strawbridge RJ, Nister M, Brismar K, Li C, Lindstrom S. Influence of $\mathrm{MUCl}$ genetic variation on prostate cancer risk and survival. Eur J Hum Genet. 2008;16(12):1521-5. https://doi.org/10.1038/ ejh. 2008.131

31. Wong N, Major P, Kapoor A, Wei F, Yan J, Aziz T, et al. Amplification of MUCl in prostate cancer metastasis and CRPC development. Oncotarget. 2016;7(50):83115-33. https://doi.org/10.18632/ oncotarget. 13073

32. Borno ST, Fischer A, Kerick M, Falth M, Laible M, Brase JC, et al. Genome-wide DNA methylation events in TMPRSS2-ERG fusion-negative prostate cancers implicate an EZH2-dependent mechanism with miR-26a hypermethylation. Cancer Discov. 2012;2(11):1024-35. https://doi.org/10.1158/21598290.CD-12-0041

33. Kumar-Sinha C, Tomlins SA, Chinnaiyan AM. Recurrent gene fusions in prostate cancer. Nat Rev Cancer. 2008;8(7):497-511. https://doi.org/10.1038/nrc2402

34. Zoni E, Karkampouna S, Thalmann GN, Kruithof-de Julio M, Spahn M. Emerging aspects of microRNA interaction with TMPRSS2-ERG and endocrine therapy. Mol Cell Endocrinol. 2018;462 (Pt A):9-16. https://doi.org/10.1016/j.mce.2017.02.009

35. Lapointe J, Li C, Higgins JP, van de Rijn M, Bair E, Montgomery K, et al. Gene expression profiling identifies clinically relevant subtypes of prostate cancer. Proc Natl Acad Sci U S A. 2004;101(3): 811-6. https://doi.org/10.1073/pnas.0304146101

36. Taylor BS, Schultz N, Hieronymus H, Gopalan A, Xiao Y, Carver BS, et al. Integrative genomic profiling of human prostate cancer. Cancer Cell. 2010;18(1):11-22. https://doi.org/10.1016/j.ccr.2010.05.026

37. Burchell J, Gendler S, Taylor-Papadimitriou J, Girling A, Lewis A, Millis R, et al. Development and characterization of breast cancer reactive monoclonal antibodies directed to the core protein of the human milk mucin. Cancer Res. 1987;47(20):5476-82.

38. Schut IC, Waterfall PM, Ross M, O'Sullivan C, Miller WR, Habib FK, et al. MUCl expression, splice variant and short form transcription $(\mathrm{MUCl} / \mathrm{Z}, \mathrm{MUCl} / \mathrm{Y})$ in prostate cell lines and tissue. BJU Int. 2003;91(3):278-83. https://doi.org/10.1046/j.1464-410X.2003.03062.x

39. Burke PA, Gregg JP, Bakhtiar B, Beckett LA, Denardo GL, Albrecht H, et al. Characterization of MUC1 glycoprotein on prostate cancer for selection of targeting molecules. Int J Oncol. 2006;29(1):49-55. https://doi.org/10.3892/ijo.29.1.49

40. Cozzi PJ, Wang J, Delprado W, Perkins AC, Allen BJ, Russell PJ, et al. MUC1, MUC2, MUC4, MUC5AC and MUC6 expression in the progression of prostate cancer. Clin Exp Metastasis. 2005;22(7):565-73. https://doi.org/10.1007/s10585-005-5376-z 
41. Zhang S, Zhang HS, Reuter VE, Slovin SF, Scher HI, Livingston PO. Expression of potential target antigens for immunotherapy on primary and metastatic prostate cancers. Clin Cancer Res. 1998;4(2):295-302.

42. Yamamoto M, Bhavanandan VP, Nakamori S, Irimura T. A novel monoclonal antibody specific for sialylated MUCl mucin. Jpn J Cancer Res. 1996;87(5):488-96. https://doi.org/10.1111/j.13497006.1996.tb00250.x

43. Takeuchi H, Kato K, Denda-Nagai K, Hanisch FG, Clausen H, Irimura T. The epitope recognized by the unique anti-MUCl monoclonal antibody MY.1E12 involves sialyl alpha 2-3galactosyl beta 1-3N-acetylgalactosaminide linked to a distinct threonine residue in the MUCl tandem repeat. J Immunol Methods. 2002;270(2):199-209. https://doi.org/10.1016/S0022-1759(02)00298-3

44. Arai T, Fujita K, Fujime M, Irimura T. Expression of sialylated MUCl in prostate cancer: relationship to clinical stage and prognosis. Int J Urol. 2005;12(7):654-61. https://doi.org/10.1111/ j.1442-2042.2005.01112.x

45. Chen Z, Gulzar ZG, St Hill CA, Walcheck B, Brooks JD. Increased expression of GCNTI is associated with altered O-glycosylation of PSA, PAP, and MUCl in human prostate cancers. Prostate. 2014;74(10):1059-67. https://doi.org/10.1002/pros.22826

46. Rabiau N, Dechelotte P, Guy L, Satih S, Bosviel R, Fontana L, et al. Immunohistochemical staining of mucin 1 in prostate tissues. In Vivo. 2009;23(2):203-7.

47. O'Connor JC, Julian J, Lim SD, Carson DD. MUCl expression in human prostate cancer cell lines and primary tumors. Prostate Cancer Prostatic Dis. 2005;8(1):36-44.

48. Rybak AP, He L, Kapoor A, Cutz JC, Tang D. Characterization of sphere-propagating cells with stemlike properties from DU145 prostate cancer cells. Biochimica et biophysica acta. 2011;1813(5):68394. https://doi.org/10.1016/j.bbamcr.2011.01.018

49. Hikita ST, Kosik KS, Clegg DO, Bamdad C. MUCl* mediates the growth of human pluripotent stem cells. PloS one. 2008;3(10):e3312. https://doi.org/10.1371/journal.pone.0003312

50. Mei W, Lin X, Kapoor A, Gu Y, Zhao K, Tang D. The Contributions of Prostate Cancer Stem Cells in Prostate Cancer Initiation and Metastasis. Cancers. 2019;11(4). https://doi.org/10.3390/ cancers 11040434

51. Lin X, Gu Y, Kapoor A, Wei F, Aziz T, Ojo D, et al. Overexpression of MUCl and Genomic Alterations in Its Network Associate with Prostate Cancer Progression. Neoplasia. 2017;19(11):857-67. https:// doi.org/10.1016/j.neo.2017.06.006

52. Yasumizu Y, Rajabi H, Jin C, Hata T, Pitroda S, Long MD, et al. MUCl-C regulates lineage plasticity driving progression to neuroendocrine prostate cancer. Nat Commun. 2020;11(1):338. https://doi. org/10.1038/s41467-019-14219-6

53. Rajabi H, Ahmad R, Jin C, Joshi MD, Guha M, Alam M, et al. MUCl-C oncoprotein confers androgen-independent growth of human prostate cancer cells. Prostate. 2012;72(15):1659-68. https://doi. org/10.1002/pros.22519

54. Rajabi H, Joshi MD, Jin C, Ahmad R, Kufe D. Androgen receptor regulates expression of the MUC1-C oncoprotein in human prostate cancer cells. Prostate. 2011;71(12):1299-308. https://doi. org/10.1002/pros.21344

55. Mitchell S, Abel P, Ware M, Stamp G, Lalani E. Phenotypic and genotypic characterization of commonly used human prostatic cell lines. BJU Int. 2000;85(7):932-44. https://doi. org/10.1046/j.1464-410x.2000.00606.x

56. Evangelou A, Letarte M, Marks A, Brown TJ. Androgen modulation of adhesion and antiadhesion molecules in PC-3 prostate cancer cells expressing androgen receptor. Endocrinology. 2002;143(10):3897-904. https://doi.org/10.1210/en.2002-220156

57. Mitchell S, Abel P, Madaan S, Jeffs J, Chaudhary K, Stamp G, et al. Androgen-dependent regulation of human MUCl mucin expression. Neoplasia. 2002;4(1):9-18. https://doi.org/10.1038/sj.neo.7900194

58. Huang DM, Guh JH, Chueh SC, Teng CM. Modulation of anti-adhesion molecule MUC-1 is associated with arctiin-induced growth inhibition in PC-3 cells. Prostate. 2004;59(3):260-7. https://doi. org/10.1002/pros.10364

59. Chachadi VB, Ali MF, Cheng PW. Prostatic cell-specific regulation of the synthesis of MUCl-associated sialyl Lewis a. PloS one. 2013;8(2):e57416. https://doi.org/10.1371/journal.pone.0057416 
60. Hey NA, Aplin JD. Sialyl-Lewis x and Sialyl-Lewis a are associated with MUCl in human endometrium. Glycoconj J. 1996;13(5):769-79. https://doi.org/10.1007/BF00702341

61. Zhang K, Baeckstrom D, Brevinge H, Hansson GC. Comparison of sialyl-Lewis a-carrying CD43 and MUCl mucins secreted from a colon carcinoma cell line for E-selectin binding and inhibition of leukocyte adhesion. Tumour Biol. 1997;18(3):175-87. https://doi.org/10.1159/000218028

62. Fernandez-Rodriguez J, Dwir O, Alon R, Hansson GC. Tumor cell MUCl and CD43 are glycosylated differently with sialyl-Lewis a and $\mathrm{x}$ epitopes and show variable interactions with E-selectin under physiological flow conditions. Glycoconj J. 2001;18(11-12):925-30. https://doi. org/10.1023/A:1022208727512

63. Borsig L. Selectins in cancer immunity. Glycobiology. 2018;28(9):648-55. https://doi.org/10.1093/ glycob/cwx105

64. Xiang S, Zhang Q, Tang Q, Zheng F, Wu J, Yang L, et al. Activation of AMPKalpha mediates additive effects of solamargine and metformin on suppressing $\mathrm{MUCl}$ expression in castration-resistant prostate cancer cells. Sci Rep. 2016;6:36721. https://doi.org/10.1038/srep36721

65. Papadopoulos I, Sivridis E, Giatromanolaki A, Koukourakis MI. Tumor angiogenesis is associated with $\mathrm{MUCl}$ overexpression and loss of prostate-specific antigen expression in prostate cancer. Clin Cancer Res. 2001;7(6):1533-8.

66. Okamoto T, Yoneyama MS, Hatakeyama S, Mori K, Yamamoto H, Koie T, et al. Core2 O-glycanexpressing prostate cancer cells are resistant to NK cell immunity. Mol Med Rep. 2013;7(2):359-64. https://doi.org/10.3892/mmr.2012.1189

67. Liang X, Li Z, Men Q, Li Y, Li H, Chong T. miR-326 functions as a tumor suppressor in human prostatic carcinoma by targeting Mucinl. Biomed Pharmacother. 2018;108:574-83. https://doi. org/10.1016/j.biopha.2018.09.053

68. Genitsch V, Zlobec I, Thalmann GN, Fleischmann A. MUCl is upregulated in advanced prostate cancer and is an independent prognostic factor. Prostate Cancer Prostatic Dis. 2016;19(3):242-7. https://doi.org/10.1038/pcan.2016.11

69. Eminaga O, Wei W, Hawley SJ, Auman H, Newcomb LF, Simko J, et al. MUCl Expression by Immunohistochemistry Is Associated with Adverse Pathologic Features in Prostate Cancer: A Multi-Institutional Study. PloS one. 2016;11(11):e0165236. https://doi.org/10.1371/journal. pone. 0165236

70. Severi G, FitzGerald LM, Muller DC, Pedersen J, Longano A, Southey MC, et al. A three-protein biomarker panel assessed in diagnostic tissue predicts death from prostate cancer for men with localized disease. Cancer Med. 2014;3(5):1266-74. https://doi.org/10.1002/cam4.281

71. Jiang Y, Mei W, Gu Y, Lin X, He L, Zeng H, et al. Construction of a set of novel and robust gene expression signatures predicting prostate cancer recurrence. Mol Oncol. 2018;12(9):1559-78. https://doi. org/10.1002/1878-0261.12359

72. Andren O, Fall K, Andersson SO, Rubin MA, Bismar TA, Karlsson M, et al. MUC-1 gene is associated with prostate cancer death: a 20-year follow-up of a population-based study in Sweden. Br J Cancer. 2007;97(6):730-4. https://doi.org/10.1038/sj.bjc.6603944

73. Premaratne P, Welen K, Damber JE, Hansson GC, Backstrom M. O-glycosylation of MUC1 mucin in prostate cancer and the effects of its expression on tumor growth in a prostate cancer xenograft model. Tumour Biol. 2011;32(1):203-13. https://doi.org/10.1007/s13277-010-0114-9

74. Sanchez C, Chan R, Bajgain P, Rambally S, Palapattu G, Mims M, et al. Combining T-cell immunotherapy and anti-androgen therapy for prostate cancer. Prostate Cancer Prostatic Dis. 2013;16(2):123-31, S1. https://doi.org/10.1038/pcan.2012.49

75. Gao T, Cen Q, Lei H. A review on development of MUCl-based cancer vaccine. Biomed Pharmacother. 2020;132:110888. https://doi.org/10.1016/j.biopha.2020.110888

76. Palmer M, Parker J, Modi S, Butts C, Smylie M, Meikle A, et al. Phase I study of the BLP25 (MUC1 peptide) liposomal vaccine for active specific immunotherapy in stage IIIB/IV non-small-cell lung cancer. Clin Lung Cancer. 2001;3(1):49-57; https://doi.org/10.3816/CLC.2001.n.018

77. North SA, Graham K, Bodnar D, Venner P. A pilot study of the liposomal MUCl vaccine BLP25 in prostate specific antigen failures after radical prostatectomy. J Urol. 2006;176(1):91-5. https://doi. org/10.1016/S0022-5347(06)00494-0 
78. Scheid E, Major P, Bergeron A, Finn OJ, Salter RD, Eady R, et al. Tn-MUCl DC Vaccination of Rhesus Macaques and a Phase I/II Trial in Patients with Nonmetastatic Castrate-Resistant Prostate Cancer. Cancer Immunol Res. 2016;4(10):881-92. https://doi.org/10.1158/2326-6066.CIR-15-0189

79. Westdorp H, Creemers JHA, van Oort IM, Schreibelt G, Gorris MAJ, Mehra N, et al. Blood-derived dendritic cell vaccinations induce immune responses that correlate with clinical outcome in patients with chemo-naive castration-resistant prostate cancer. J Immunother Cancer. 2019;7(1):302. https:// doi.org/10.1186/s40425-019-0787-6

80. Dreicer R, Stadler WM, Ahmann FR, Whiteside T, Bizouarne N, Acres B, et al. MVA-MUC1-IL2 vaccine immunotherapy (TG4010) improves PSA doubling time in patients with prostate cancer with biochemical failure. Invest New Drugs. 2009;27(4):379-86. https://doi.org/10.1007/s10637-008-9187-3

81. Joshi MD, Ahmad R, Yin L, Raina D, Rajabi H, Bubley G, et al. MUCl oncoprotein is a druggable target in human prostate cancer cells. Mol Cancer Ther. 2009;8(11):3056-65. https://doi.org/10.1158/15357163.MCT-09-0646

82. Mazor Y, Noy R, Wels WS, Benhar I. chFRP5-ZZ-PE38, a large IgG-toxin immunoconjugate outperforms the corresponding smaller FRP5(Fv)-ETA immunotoxin in eradicating ErbB2-expressing tumor xenografts. Cancer Lett. 2007;257(1):124-35. https://doi.org/10.1016/j.canlet.2007.07.009

83. Pichinuk E, Chalik M, Benhar I, Ginat-Koton R, Ziv R, Smorodinsky NI, et al. In vivo anti-MUCl(+) tumor activity and sequences of high-affinity anti-MUCl-SEA antibodies. Cancer Immunol Immunother: CII. 2020;69(7):1337-52. https://doi.org/10.1007/s00262-020-02547-2

84. Spicer AP, Rowse GJ, Lidner TK, Gendler SJ. Delayed mammary tumor progression in Muc-1 null mice. J Biol Chem. 1995;270(50):30093-101. https://doi.org/10.1074/jbc.270.50.30093

85. Peat N, Gendler SJ, Lalani N, Duhig T, Taylor-Papadimitriou J. Tissue-specific expression of a human polymorphic epithelial mucin (MUC1) in transgenic mice. Cancer Res. 1992;52(7):1954-60. 